\title{
MANUFACTURE OF SPHERICAL GRANULES OF ISOSORBIDE DINITRATE WITH MODIFIED RELEASE
}

\author{
MODIFIIYE SALIMLI ISOSORBITT DINITRAT KÜRESEL GRANÜLLERININN ÜRETIMİ
}

\section{Dmytro OLIINYKOV ${ }^{1, *}$, Andrii KAPLAUSHENKO${ }^{1}$, Svitlana TREGUB ${ }^{2}$, Katerina KOVALYOVA}

${ }^{1}$ Zaporizhzhia State Medical University, Faculty of Pharmacy, Department of Physical and Colloidal Chemistry, 69035, Zaporizhzhia, Ukraine

${ }^{2}$ Zaporizhzhia State Medical University, International Faculty, Department of Foreign Languages, 69035, Zaporizhzhia, Ukraine

${ }^{3}$ National University of Pharmacy, Faculty of Pharmacy, Department of Inorganic Chemistry, 61002, Kharkiv, Ukraine

\begin{abstract}
Objective: This study was aimed to obtain spherical matrix pellets of isosorbide dinitrate with different dissolution kinetics to create a multidosage medicinal form with controlled release of the active substance.

Material and Method: Spherical matrix granules were obtained by extrusion-spherinization and coated with different amounts of polymer shell. Dissolution profiles of the obtained spheroids were compared with reference drug tablets.

Result and Discussion: The results showed that the combination of spherical granules provides an isosorbide dinitrate release profile similar to the dissolution of Cardicet Retard tablets. The target dissolution profile is achieved using a combination of uncoated spherical granules and spheroids with a 10\% film coating. The similarity coefficient $(f 2)$ is 73.6 .

Keywords: Isosorbide dinitrate, release profile, spherical matrix pellets

ÖZ

Amaç: Bu çalış̧a, etkin maddenin kontrollü salımın yapan çok dozlu bir tıbbi form oluşturmak için farkl çözünme kinetiklerine sahip izosorbit dinitratın küresel matris pelletlerini elde etmeyi amaçlamıștır.
\end{abstract}

\footnotetext{
* Corresponding Author/Sorumlu Yazar: Dmytro Oliinykov

e-mail / e-posta: oleynikov@ microkhim.com, Phone / Tel.: +380663780082
} 
Gereç ve Yöntem: Küresel matris granüller ekstrüder-sferonizer yöntemi ile elde edilmiş ve farklı miktarlarda polimer kabuk ile kaplanmıştır. Elde edilen kürelerin çözünme profilleri, referans ilaç tabletleri ile karşılaştırılmıştır.

Sonuç ve Tartışma: Sonuçlar, küresel granüllerin kombinasyonunun, Cardicet Retard tabletlerinin çözünmesine benzer bir izosorbit dinitrat salım profili să̆ladiğını göstermiştir. Hedef çözünme profili, kaplanmamış küresel granüller ve \% 10'luk film kaplı kürelerin bir kombinasyonu kullanılarak elde edilmiştir. Benzerlik katsayısı (f2) 73.6'dır.

Anahtar Kelimeler: Isosorbit dinitrat, salım profili, küresel matriks pelletler

\section{INTRODUCTION}

Isosorbide dinitrate belongs to the group of first choice drugs for the treatment of angina pectoris. Prolonged forms of isosorbide dinitrate have high preventive efficacy. Modified-release drugs can combine high pharmacological activity, a long period of therapeutic action, and serious side effects absence, which are characteristic to all nitrate group drugs. The need of up-to-date cardiac drugs with a high level of efficacy and safety necessitates the development of modified-release drugs, primarily for oral administration $[1,2]$.

Multicomponent medicinal forms are becoming more widely used, in comparison with monolithic medicinal forms. They have a number of potential benefits, such as predicted gastrointestinal movement, overdose risk absence, ability to manage the release profile, increased bioavailability, and also less intra-subject and inter-subject variability in pharmacokinetic characteristics $[3,4]$.

Pellets, or spherical granulas, are one of the most popular medicinal multidosage forms. Granulation is an agglomeration process, that converts fine powders or particles of drugs and additional components into small spherical or hemispherical pellets. Pelletizing technologies provide a large corridor of capabilities and can be performed in various required dosages without changing the manufacturing process. Typically, spherical pellets are 0.5 to $1.5 \mathrm{~mm}$ in size and are generally used to achieve sustained release. After receiving the drug, the pellets are evenly distributed over a large volume of the gastrointestinal tract, which leads to the release of the active component with reduced risk of local irritation and minimizes the possibility of overdose $[4,5]$.

The purpose of this study is to obtain spherical matrix pellets of isosorbide dinitrate with different dissolution kinetics to create a multidosage medicinal form with controlled release of the active substance. Matrix tablets, despite the simplicity of the technology, have the risk of dose breakthrough and overdose, which is especially critical for substances with a narrow therapeutic range, such as nitrates. Unlike matrix tablets Cardiket Retard, this innovative form will allow you to create the necessary release profile of the active ingredient through the combination of granules 
without the risk of possible overdose.

Extrusion-spheronization technology is the most popular method of the pellet production.

The advantages of the extrusion-spheronization in comparison with other methods are $[6,7]$ :

- the possibility of achieving higher content of the active component;

- in the pellets some ratio of several active substances can be combined in;

- the possibility of leveling unwanted physical characteristics of the active ingredients (low bulk density, hygroscopicity) through the use of various inert fillers;

- high density of the obtained pellets and narrow size distribution;

- smoother pellet surface in comparison with other technologies.

For the manufacturing of isosorbide dinitrate pellets, it is advisable to use the extrusionspheronization method to obtain dense smooth pellets with a high drug content [8].

\section{MATERIAL AND METHOD}

\section{Reference drug}

In order to determine the reference release profile of isosorbide dinitrate for matrix granules, prolonged-release tablets "Cardiket Retard" 40 mg (Aesica Pharmaceuticals GmbH, Germany) were used.

\section{Excipients, which were used}

Isosorbide dinitrate (RPF "MICROKHIM", Ukraine)

Polyacrylate dispersion of Eudragit NE 30D (Evonik, Germany)

Microcrystalline Cellulose HEWETEN 101 (JRS Pharma, USA)

Lactose monohydrate Pharmatose 200M (DFE Pharma, Germany)

Hydroxypropylmethylcellulose Mantrocel E-6 (Mantrose-Haeuser, USA)

Talc (Imifabi, USA)

\section{Obtaining of spherical pellets}

Spherical matrix pellets of isosorbide dinitrate were obtained by the extrusion-spheronization, by means of Eudragit NE 30D as a polymer, that provides modified release.

The weighed amounts of the solids were mixed in a drum mixer HSD5-100 (SaintyCo, China). The resulting dry mixture was moistened with an aqueous Eudragit NE 30D dispersion and mixed in a planetary granulator-mixer XF DH-5L (Nantong KMM, China). The resulting plastic mass was extruded on a screw radial extruder YC-910 (Pilotech, China) with a screen diameter of $0.75 \mathrm{~mm}$. 
The obtained extrudate was spheronized in a laboratory unit for spheronization and film coating on spherical granules YC-910 (Pilotech, China) equipped with a $250 \mathrm{~mm}$ diameter corrugated disc with a $2 \mathrm{~mm}$ corrugation step (900 rpm).

After spheronization, the pellets were dried in a shelf oven at $40^{\circ} \mathrm{C}$ for 24 hours.

\section{Screening of spherical pellets}

To determine the particle size composition of the obtained spherical granules and separation them into fractions, a set of stainless steel laboratory sieves with a mesh size of $0.25 \mathrm{~mm}, 0.5 \mathrm{~mm}$, $0.8 \mathrm{~mm}$ and $1.0 \mathrm{~mm}$ was used [9].

\section{Obtaining of coated spherical pellets}

Coating of spherical pellets with a film sheath was carried out on a laboratory unit for spheronization and film coating on spherical granules YC-910 (Pilotech, China), equipped with a smooth disk (600 rpm) and a top spray nozzle with a nozzle of $1.2 \mathrm{~mm}$.

After coating, the pellets were dried in a shelf oven at $40^{\circ} \mathrm{C}$ for 6 hours.

\section{Quantitative determination}

The content of the isosorbide dinitrate in the obtained matrix pellets was determined, by means of their own validated analytical HPLC - technique. The analysis was performed on a Shimadzu LC20AD XR liquid chromatograph with a diode-array detector under the following conditions: Supelco Discovery C18 chromatographic column $(150 \times 4.6 \mathrm{~mm}, 5 \mu \mathrm{m})$; mobile phase - water $\mathrm{R}$ - buffer solution (pH 4.7) - methanol R2 (35:10:55); elution mode - isocratic; mobile phase velocity - $1.0 \mathrm{ml}$ / min; the detection wavelength is $220 \mathrm{~nm}$ [10].

To prepare buffer solution ( $\mathrm{pH}$ 4.7) $15.4 \mathrm{~g}$ of ammonium acetate $\mathrm{R}$ was made into a volumetric flask with a capacity of $1000.0 \mathrm{ml}$, was added $300.0 \mathrm{ml}$ of water $\mathrm{R}, 11.5 \mathrm{ml}$ of glacial acetic acid R, mixed and adjusted the volume solution with water to the mark. The $\mathrm{pH}$ of the solution was adjusted as needed with glacial acetic acid $\mathrm{R}$.

To prepare a comparison solution of $0.120 \mathrm{~g}$ (exact portion) CRS isosorbide dinitrate was added to a volumetric flask with a capacity of $500.0 \mathrm{ml}$, was added $300 \mathrm{ml}$ of methanol R2 and kept in an ultrasonic bath for 10 minutes, bring the volume of the solution to the mark methanol R2 and mixed thoroughly.

To prepare the test solution, about $0.24 \mathrm{~g}$ (exact portion) powder of ground matrix granules was made into a volumetric flask with a capacity of $200.0 \mathrm{ml}$, was added $100 \mathrm{ml}$ of methanol R2 and kept on ultrasound bath for 30 minutes at $40-50^{\circ} \mathrm{C}$, adjusted the volume of the solution to the mark 
with methanol R2 and mixed thoroughly. $25.00 \mathrm{ml}$ obtained the solution was transferred to a volumetric flask with a capacity $50.0 \mathrm{ml}$ and adjusted the volume of the solution with the mobile phase to the mark, mixed thoroughly and filtered through the PES syringe filter ( $d=25 \mathrm{~mm}, 0.45$ $\mu \mathrm{m})$ or similar, discarding the first portions of the filter installment [10].

\section{Dissolution of matrix pellets}

Dissolution Tester - COPLEY DIS 6000 (Copley, UK).

For testing apparatus 1 - with a basket was used.

The rotation speed of the basket is $100 \mathrm{rpm}$.

The dissolution medium is water.

The volume of dissolution medium is $500 \mathrm{ml}$.

The temperature of dissolution medium is $37 \pm 0.5^{\circ} \mathrm{C}$.

The dissolution time is 12 hours.

To test $100 \mathrm{mg}$ of matrix pellets (which approximately corresponds to $40 \mathrm{mg}$ of isosorbide dinitrate) or 1 tablet "Cardiket Retard" $40 \mathrm{mg}$ were placed in baskets. All 6 baskets are lowered into glasses, so the entire volume of the basket, along with the contents, is completely immersed in liquid. After 1 hour of dissolution $10 \mathrm{ml}$ of solution was selected from the center of the glass, filtered through a paper filter "blue ribbon", discarding the first portions of the filtrate. The sample was diluted 1:1 with water R. After 1, 2, 4, 6, 8, 10 and 12 hours from the beginning of the dissolution, the samples were repeated in a similar manner.

Preparation of standard isosorbide dinitrate solution is: a sample of isosorbide dinitrate CRS equivalent to $0.050 \mathrm{~g}$ of $100 \%$ isosorbide dinitrate is placed into a $50.0 \mathrm{ml}$ volumetric flask, $2 / 3$ flask of methanol R2 is added, it is kept in an ultrasonic bath for 10 minutes, it is brought by the volume of methanol $\mathrm{R} 2$ to the mark and stirred. $1 \mathrm{ml}$ of the resulting solution is transferred into a volumetric flask with a capacity of $25.0 \mathrm{ml}$, bring the volume of the solution with water $\mathrm{R}$ to the mark and mix.

Preparation of a buffer solution with a $\mathrm{pH}$ of $4.7: 15.4 \mathrm{~g}$ of ammonium acetate $\mathrm{R}$ is placed in a volumetric flask with a capacity of $1000.0 \mathrm{ml}$, it is added $300.0 \mathrm{ml}$ of water $\mathrm{R}, 11.5 \mathrm{ml}$ of glacial acetic acid, mix and bring the volume of the solution water R to the mark. If necessary, the $\mathrm{pH}$ of the solution with glacial acetic acid $\mathrm{R}$ is adjusted potentiometrically.

$50 \mu \mathrm{l}$ of the test solution and $50 \mu \mathrm{l}$ of the standard isosorbide dinitrate solution are chromatographed on a liquid chromatograph with a UV detector, receiving at least 3 chromatograms for each of the solutions under the following conditions:

- a column of $150 \times 4,6 \mathrm{~mm}$ in size is filled with LS-18 sorbent;

- mobile phase: water R is a buffer solution with $\mathrm{pH} 4.7$ is methanol R2 (350: 100: 550); 
- the speed of the mobile phase is $1.0 \mathrm{ml} / \mathrm{per} \mathrm{min}$;

- detection at a wavelength is $210 \mathrm{~nm}$.

\section{Comparison of dissolution profiles}

To compare the dissolution profiles of matrix granules and tablets, the similarity factor $\mathbf{f} 2$ was calculated according to the formula [11]:

$$
\mathrm{f}_{2}=50 \cdot \log \left\{\left[1+(1 / \mathrm{n}) \sum_{\mathrm{i}=1}^{\mathrm{n}}\left|\mathrm{R}_{\mathrm{i}}-\mathrm{T}_{\mathrm{i}}\right|^{2}\right]^{-0,5} \cdot 100\right\},
$$

where $\mathbf{n}$ is the number of time points; $\mathbf{R i}$ is the amount of active substance transferred to the solution from the comparison drug at the $\mathrm{i}$-th time point (on average, \%); $\mathbf{T i}$ is the amount of active substance transferred to the solution from the test drug at the i-th time point (on average, \%).

The value of $\mathbf{f} 2$, which is in the range from 50 to 100, indicates a similar dissolution kinetics of drugs.

\section{RESULT AND DISCUSSION}

\section{Selection of excipients}

As an excipient for the manufacture of granules by extrusion-spheronization is most often used microcrystalline cellulose (MCC). Water is an acceptable moisturizer for use with microcrystalline cellulose. The use of lactose as a filler is unacceptable when moistened with water due to its high solubility. However, binary mixtures of microcrystalline cellulose and lactose retain the absorption and adsorption properties of MCC, which are absent or minimal in the compositions with lactose [7].

Lactose was included into the pellets to provide complete leaching from the matrix of the active component, because isosorbide dinitrate has low solubility in aqueous media, and virtually all other components of the composition are insoluble in water. Lactose is taken in an amount about in 10 times smaller, then microcrystalline cellulose. This approach allows to preserve as much as possible for the mixture the physical and technological properties of the MCC to ensure an efficient process of the extrusion-spheronization.

As the polymer, that modifies the release of the active component, polyacrylate copolymer in the form of an aqueous 30\% dispersion of Eudragit NE 30D was selected. This polymer is insoluble in water, has low permeability and its properties are independent of the $\mathrm{pH}$ of the medium. The Eudragit NE 30D is also highly ductile and it doesn't require plasticizer. The product does not require 
the use in organic solvent technology and it is therefore absolutely safe. These properties make polyacrylate dispersion the most suitable product for both wet granulation and film coating, which regulates the release of the active substance [12].

Low viscosity hydroxypropylmethylcellulose (HPMC) is added to the composition to create stickiness. To ensure the necessary properties, the HPMC was taken in a mass ratio of 1:19 to microcrystalline cellulose [13].

\section{Obtaining of spherical pellets}

The number of components per 1 extrusion-spheronization operation is shown in table 1 .

Table 1. Downloaded component masses per one extrusion-spheronization operation.

\begin{tabular}{|c|c|c|}
\hline Component & $\mathbf{g}$ & $\mathbf{\%}$ \\
\hline Isosorbide dinitrate & 120 & 40 \\
\hline Microcrystalline cellulose & 114 & 38 \\
\hline Lactose monohydrate & 15 & 5 \\
\hline Eudragit NE 30D & 150 (45 anhydrous) & 15 \\
\hline Hydroxypropylmethylcellulose & 6 & 2 \\
\hline Together: & 405 & 100 \\
\hline
\end{tabular}

The resulting spherical pellets were dried, then the combined number of spheroids from 10 operations were scattered on laboratory sieves. The scattering results are shown in table 2.

Table 2. Fractional composition of spherical matrix pellets.

\begin{tabular}{|c|c|c|}
\hline Fraction of pellets , mm & g & \% \\
\hline$<\mathbf{0 , 2 5}$ & 7,3 & 0,24 \\
\hline $\mathbf{0 , 2 5 - \mathbf { 0 , 5 }}$ & 94,3 & 3,14 \\
\hline $\mathbf{0 , 5}-\mathbf{0 , 8}$ & 2027,6 & 67,59 \\
\hline $\mathbf{0 , 8}-\mathbf{1 , 0}$ & 763,9 & 25,46 \\
\hline$>\mathbf{1 , 0}$ & 35,4 & 1,18 \\
\hline Together : & 2928,5 & 97,61 \\
\hline
\end{tabular}

The main part of the obtained spherical matrix pellets, as expected, was represented by a fraction of $0.5 \mathrm{~mm}$ to $1.0 \mathrm{~mm}$. Mechanical loss (the "dead" residue in the extruder; the mass adhered to the disk, etc.) was about $2 \%$ of the mass. The total yield of fractions $0.5-0.8 \mathrm{~mm}$ and $0.8-1.0$ $\mathrm{mm}$ is more than $90 \%$. Pellets of these sizes were of interest for further use in modified release medicinal forms.

The release profiles of isosorbide dinitrate from the obtained pellets are presented in table 3 and on the figure 1. 
Table 3. Results of matrix pellets' dissolution of isosorbide dinitrate and tablets Cardiket Retard 40 $\mathrm{mg}$

\begin{tabular}{|c|c|c|c|}
\hline$\frac{\text { Index }}{\text { Ouantitative determination \% }}$ & $\begin{array}{c}0.5-0.8 \mathrm{~mm} \\
\text { fraction }\end{array}$ & $\begin{array}{c}0.8-1.0 \mathrm{~mm} \\
\text { fraction }\end{array}$ & \multirow{2}{*}{$\begin{array}{c}\text { Cardiket Retard } \\
40 \mathrm{mg}\end{array}$} \\
\hline Quantitative determination, \% & 39,7 & 39,5 & \\
\hline Dissolution time, hours & \multicolumn{3}{|c|}{$\%$ released isosorbide dinitrate \pm SD } \\
\hline $\mathbf{0}$ & 0,0 & 0,0 & 0,0 \\
\hline 1 & $45,22 \pm 2,14$ & $39,94 \pm 2,13$ & $22,27 \pm 2,04$ \\
\hline 2 & $60,69 \pm 2,23$ & $53,57 \pm 2,36$ & $34,08 \pm 2,73$ \\
\hline 4 & $79,50 \pm 2,74$ & $73,19 \pm 3,16$ & $53,23 \pm 2,56$ \\
\hline 6 & $91,24 \pm 3,42$ & $84,12 \pm 3,21$ & $66,55 \pm 3,20$ \\
\hline 8 & $97,53 \pm 4,03$ & $92,82 \pm 3,67$ & $75,92 \pm 3,58$ \\
\hline 10 & $100,38 \pm 4,15$ & $97,83 \pm 3,79$ & $83,31 \pm 4,07$ \\
\hline 12 & $101,41 \pm 4,43$ & $99,68 \pm 4,29$ & $88,60 \pm 4,74$ \\
\hline
\end{tabular}

In 12 hours, almost complete dissolution of the tablet Cardiket Retard (about 90\%), which is consistent with the instructions for use of the drug (taken 1-2 times a day).

More than $80 \%$ of the dose of isosorbide dinitrate is released from the obtained matrix granules in 6 hours. For more effective prolongation on the matrix granules it is necessary to apply a shell that regulates the dissolution rate of the active ingredient.

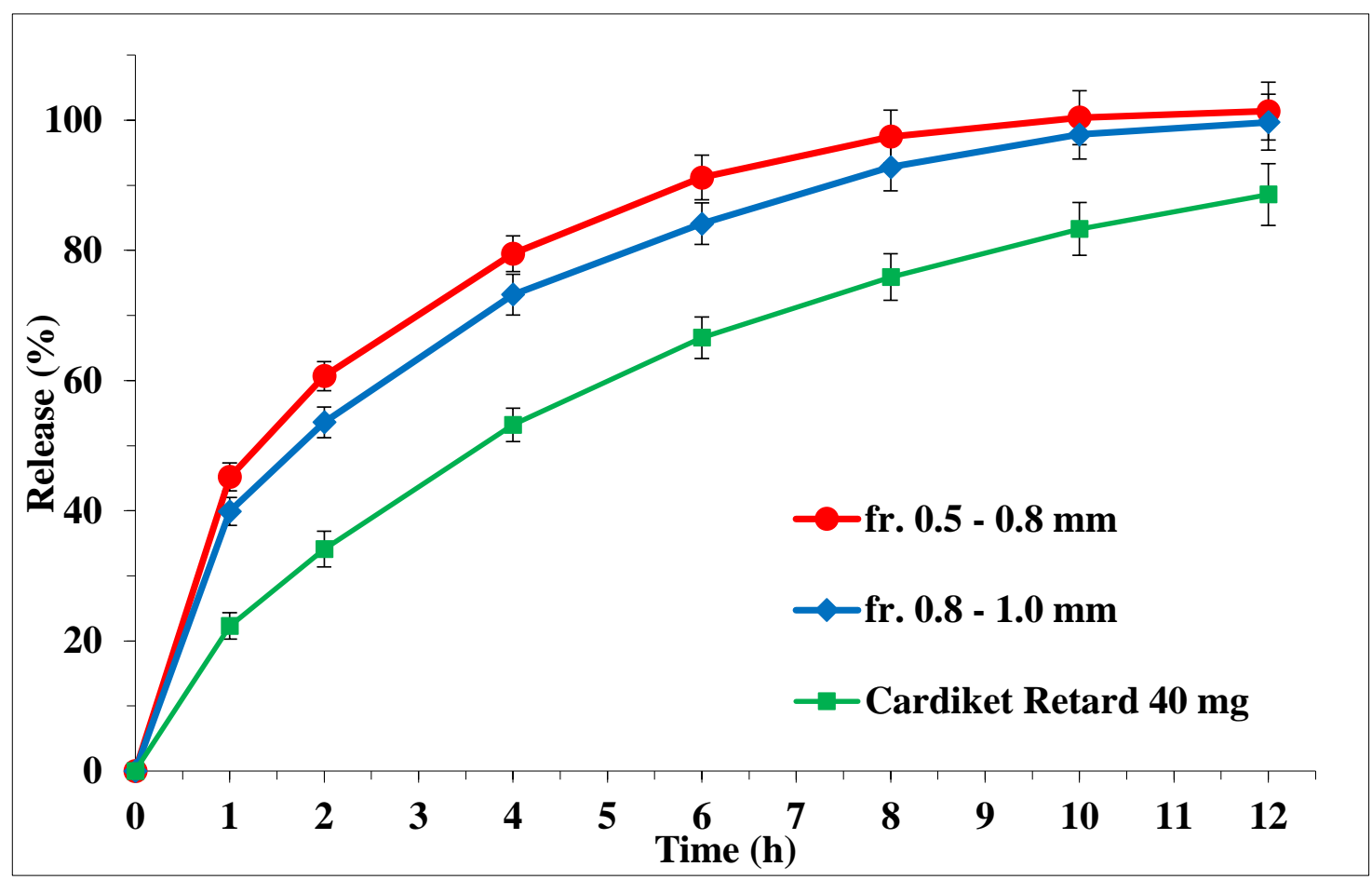

Figure 1. Isosorbide dinitrate release profiles from matrix pellets and tablets Cardiket Retard $40 \mathrm{mg}$. 


\section{Obtaining of coated spherical pellets}

Spheroids of $0.5-0.8 \mathrm{~mm}$ fraction were used to obtain coated matrix granules. Spheroids of the fraction of $0.8-1.0 \mathrm{~mm}$ can be used without coating for combination with coated granules, as their dissolution profile is slightly lower.

In order to select the optimal amount of coating on the spheroids applied different portions of the polymer shell $(5,10,15$ and $20 \%$ by weight of the granules). For each of the variants of the amount of coating did 2 application operations. For 1 operation took $250 \mathrm{~g}$ of granules. The composition of the suspension, which was applied to the matrix spheroids, is shown in table 4 .

Table 4. The composition of the suspension applied on the matrix pellets

\begin{tabular}{|c|c|}
\hline Component & Composition per 1 liter of suspension for coating \\
\hline Eudragit NE 30D & $500 \mathrm{~g}(150 \mathrm{~g}$ of dry polymer $)$ \\
\hline Talc & $150 \mathrm{~g}$ \\
\hline The purified water & up to $1000 \mathrm{ml}$ \\
\hline
\end{tabular}

The parameters of the film coating process, regulating the release of the active component are shown in table 5.

Table 5. Parameters of the film coating process on spherical matrix pellets

\begin{tabular}{|c|c|}
\hline Process parameters & Value \\
\hline Disk rotation speed & $600 \mathrm{rpm}$ \\
\hline Supplied air temperature & $29-31^{\circ} \mathrm{C}$ \\
\hline Air consumption & $40 \mathrm{~m}^{3} / \mathrm{h}$ \\
\hline Outlet air temperature & $24-26^{\circ} \mathrm{C}$ \\
\hline The spray pressure on the nozzle & $1,7 \mathrm{bar}$ \\
\hline Consumption of the applied suspension & $3 \mathrm{ml} / \mathrm{min}$ \\
\hline
\end{tabular}

The release profiles of isosorbide dinitrate from the obtained coated pellets are presented in table 6 and on the figure 2.

Table 6. The results of coated matrix pellets dissolution of isosorbide dinitrate

\begin{tabular}{|c|c|c|c|c|}
\hline Index & coated 5\% & coated $10 \%$ & coated $15 \%$ & coated $20 \%$ \\
\hline $\begin{array}{c}\text { Quantitative determination, } \\
\%\end{array}$ & 38,2 & 36,3 & 34,6 & 33,1 \\
\hline Dissolution time, hours & \multicolumn{4}{|c|}{$\%$ released isosorbide dinitrate \pm SD } \\
\hline $\mathbf{0}$ & 0,0 & 0,0 & 0,0 & 0,0 \\
\hline 1 & $19,76 \pm 2,42$ & $11,90 \pm 2,73$ & $4,28 \pm 2,54$ & $3,26 \pm 2,28$ \\
\hline 2 & $33,36 \pm 2,45$ & $21,12 \pm 2,62$ & $9,13 \pm 2,09$ & $5,73 \pm 2,39$ \\
\hline 4 & $55,71 \pm 2,88$ & $40,36 \pm 2,54$ & $20,74 \pm 2,49$ & $14,68 \pm 3,36$ \\
\hline 6 & $71,66 \pm 3,23$ & $53,82 \pm 3,09$ & $31,14 \pm 3,56$ & $23,29 \pm 3,52$ \\
\hline 8 & $86,77 \pm 3,93$ & $65,17 \pm 3,97$ & $40,82 \pm 4,12$ & $30,12 \pm 3,33$ \\
\hline 10 & $96,48 \pm 4,50$ & $75,65 \pm 4,37$ & $50,73 \pm 3,97$ & $39,16 \pm 4,54$ \\
\hline 12 & $98,13 \pm 4,67$ & $86,02 \pm 4,18$ & $59,70 \pm 5,15$ & $45,85 \pm 5,16$ \\
\hline
\end{tabular}




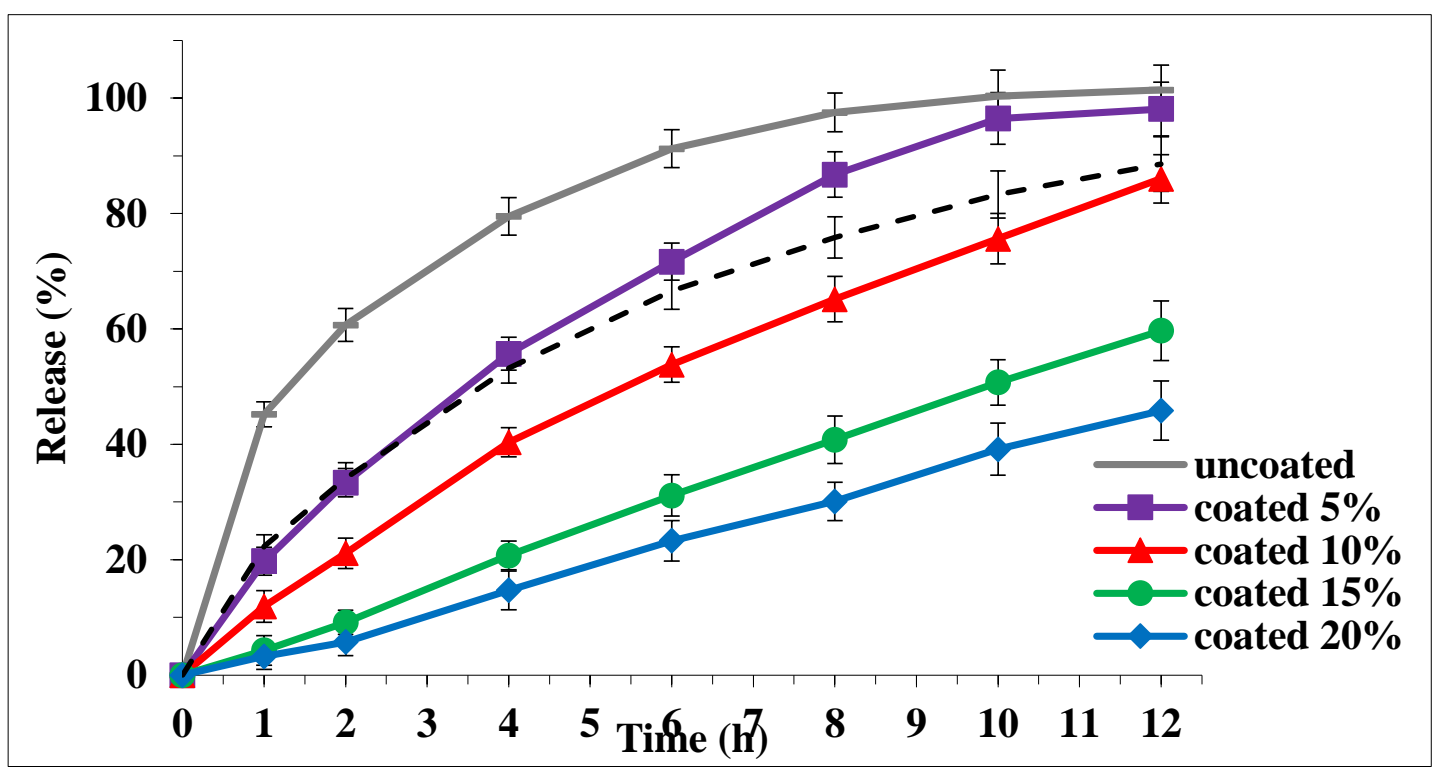

Figure 2. Release profiles of isosorbide dinitrate from coated matrix pellets

Granules with 5\% coating provide the closest release profile to the comparison drug. Spheroids with a large amount of applied coating do not have time to release even $90 \%$ of the active component in 12 hours.

To reproduce the dissolution of Cardiket Retard tablets, it is advisable to use either spheroids with a $5 \%$ coating or a combination of uncoated and coated granules.

Spheroids with $10 \%$ film coating were used for combination with uncoated granules (fr. 0.8 $1.0 \mathrm{~mm})$. The granules were taken in the ratio in which they were obtained after operation $(25,4$ : $67,59)$.

Comparative profiles of the release of isosorbide dinitrate from different combinations of granules are presented in table 7 and figure 3.

Table 7. Comparative results of dissolution of different combinations of matrix granules

\begin{tabular}{|c|c|c|c|}
\hline Index & $\begin{array}{c}\text { Combinations of } \\
\text { granules }\end{array}$ & $\begin{array}{c}\text { Coated granules } \\
\mathbf{5 \%}\end{array}$ & Cardiket Retard 40 mg \\
\hline $\begin{array}{c}\text { Dissolution time, } \\
\text { hours }\end{array}$ & \multicolumn{3}{|c|}{ \% released isosorbide dinitrate \pm SD } \\
\hline $\mathbf{0}$ & 0,0 & 0,0 & 0 \\
\hline $\mathbf{1}$ & $19,60 \pm 2,17$ & $19,76 \pm 2,42$ & $22,27 \pm 2,04$ \\
\hline $\mathbf{2}$ & $30,04 \pm 2,12$ & $33,36 \pm 2,45$ & $34,08 \pm 2,73$ \\
\hline $\mathbf{4}$ & $49,42 \pm 2,54$ & $55,71 \pm 2,88$ & $53,23 \pm 2,56$ \\
\hline $\mathbf{6}$ & $62,13 \pm 3,45$ & $71,66 \pm 3,23$ & $66,55 \pm 3,20$ \\
\hline $\mathbf{8}$ & $72,79 \pm 4,06$ & $86,77 \pm 3,93$ & $75,92 \pm 3,58$ \\
\hline $\mathbf{1 0}$ & $81,71 \pm 4,59$ & $96,48 \pm 4,50$ & $83,31 \pm 4,07$ \\
\hline $\mathbf{1 2}$ & $89,77 \pm 4,34$ & $98,13 \pm 4,67$ & $88,60 \pm 4,74$ \\
\hline \multicolumn{4}{|l|}{} \\
\hline $\mathbf{4}$ & 73,6 & 55,3 & - \\
\hline
\end{tabular}


The combination of coated and uncoated granules provides a more Cardiket-like release profile than using only coated granules with a 5\% shell. The ratio of granules in the test sample corresponds to the fractional distribution of spheroids during their operation.

For further work on the development of a multidose dosage form of isosorbide dinitrate, it was chosen to use uncoated spheroids of the fraction $0.8-1.0 \mathrm{~mm}$ and spheroids of the fraction $0.5-0.8$ $\mathrm{mm}$ with a coating of $10 \%$ by weight of the granules. The use of combination spheroids allows you to create different variations of release profiles within a 12-hour time interval.

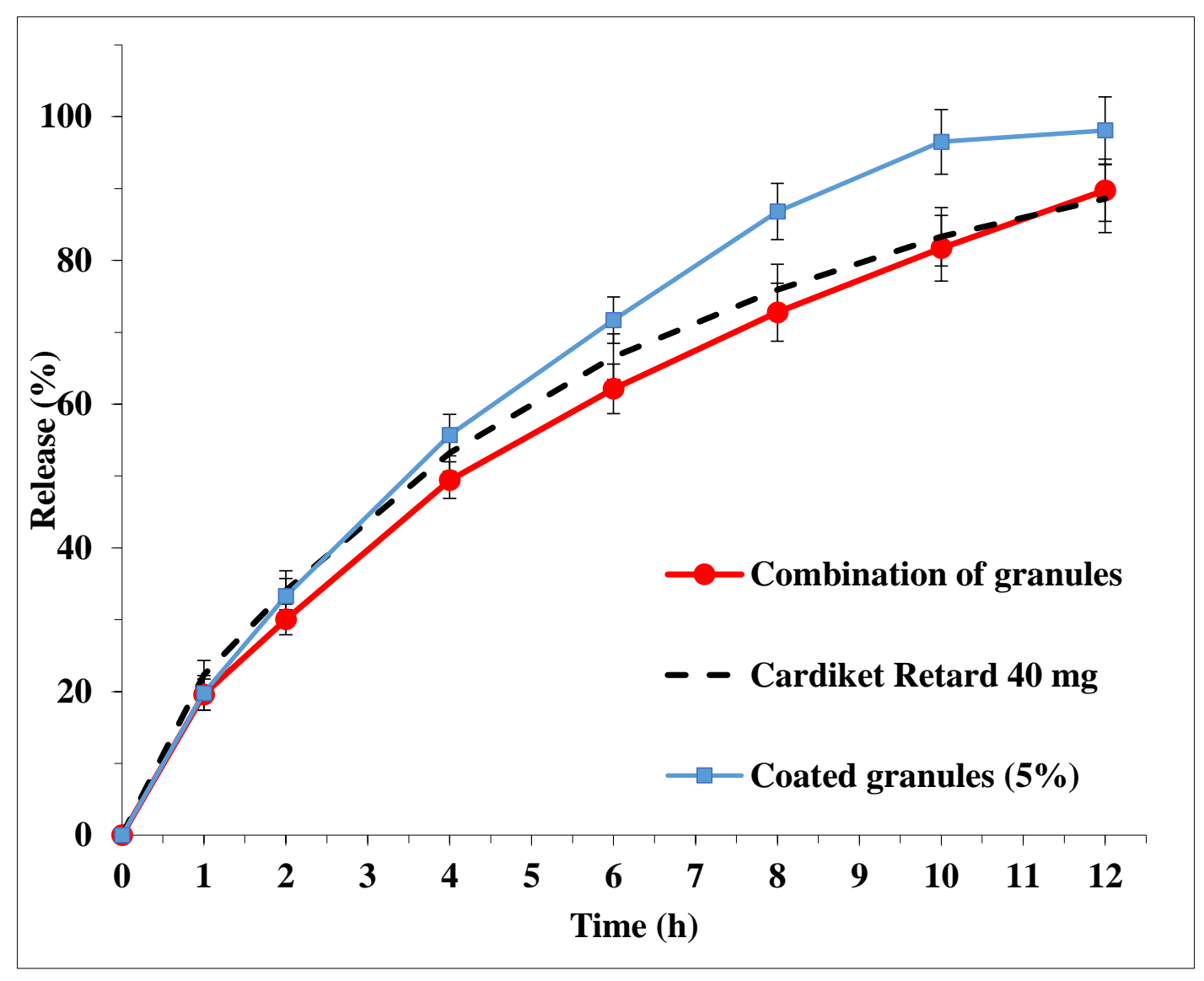

Figure 3. Comparative release profiles from different combinations of granules

\section{Conclusions}

The laboratory technology of production of matrix spherical granules of isosorbide dinitrate by extrusion-spheronization method was worked out in the work. The fractional composition of the obtained spherical granules is estimated - more than $90 \%$ of spheroids is a fraction from $0.5 \mathrm{~mm}$ to $1.0 \mathrm{~mm}$. 
The release profiles of the active substance from the obtained matrix granules, uncoated and coated with different amounts of applied polymer shell, were studied.

The use of a combination of uncoated and coated matrix granules makes it possible to achieve the required dissolution profile for multidose dosage forms.

\section{ACKNOWLEDGEMENTS}

The experimental work was performed in the research laboratory of Research-and-Production Firm «MICROKHIM». We thank the management of the company for the provided equipment and raw materials.

\section{CONFLICT OF INTEREST}

There are no conflicts of interest have been declared.

\section{REFERENCES}

1. Kovalenko, V.M., Lutaj, M.I., Bratus', V.V. et. al.; Kovalenkao, V.M. (Ed.) (2008). Rukovodstvo po kardiologii' [Guide for cardiology]. Kyiv: MORION, 1424. http://snsk.az/snsk/file/2013-06-20_09-52-44.pdf

2. Soman, B., Vijayaraghavan, G. (2017). The role of organic nitrates in the optimal medical management of angina. European Society of Cardiology 15 (2)

3. Kumar, S., Jeet, K., Baldi, A. (2015). Recent technological advancements in multiparticulate formulations: The smart drug delivery systems. Asian Journal of Pharmaceutic 9 (4): 13-25. https://www.researchgate.net/publication/28891779

4. Roy, P., Shahiwala, A. (2009). Multiparticulate formulation approach to pulsatile drug delivery: current perspectives. $J$ Control Release 134: 74-80. https://doi.org/10.1016/j.jconrel.2008.11.011

5. Shah, S., Shah, B.P., Patel,M., Patel, M.R. (2015) A review on extended release drug delivery system and multiparticulate system. World Journal of Pharmaceutical Research 4 (8):724-747. https://www.researchgate.net/publication/281098252

6. Jadhav, N., Irny, P., Mokashi, A., Souche, P., Paradkar, A. (2012). Pelletization by Extrusion Spheronization Technique: An Excipient Review. Drug Delivery Letters. 2. 132-145. https://www.researchgate.net/publication/284590372 
7. Sagar, M., Tanaji, N., Sushilkumar, P. (2016). Extrusion-spheronization a promising pelletization technique: In-depth review. Asian Journal of Pharmaceutical Sciences II: 684699. http://dx.doi.org/10.1016/j.ajps.2016.08.001

8. Oliinykov, D.S., Kaplaushenko, A.G. (2019a). Substantiation of manufacture technology development for the tablets of isosorbide dinitrate with modified release. Current issues in pharmacy and medicine: science and practice 12 (2): 160-165.

https://doi.org/10.14739/2409-2932.2019.2.170982

9. European Directorate for the Quality of Medicines et al. \& HealthCare: European Pharmacopoeia 9.0.[Internet]. 2019.

10. Oliinykov, D.S., Kaplaushenko, A.G. (2019b). Development and validation of the HPLCprocedure for the quantitative determination of isosorbide dinitrate in matrix granules. Journal of Organic and Pharmaceutical Chemistry 17 (3): 51-58. https://doi.org/10.24959/ophcj.19.174771

11. CPMP/QWP/EWP/1401/98 Rev.1/Corr** «Guideline on the Investigation of Bioequivalence»

12. Access mode: https://healthcare.evonik.com/sites/lists/NC/DocumentsHC/EvonikEudragit_brochure.pdf

13. Bhaskaran, S., Lakshmi, P.K. (2010). Extrusion Spheronization -A Review. Int.J. PharmTech Res 2(4): 2429-2433. 